\title{
On a new genus and new species of montane freshwater crab (Brachyura: Potamidae) from Genting Highlands in Peninsular Malaysia
}

Peter K. L. Ng

\begin{abstract}
A new genus and new species of potamid freshwater crab is described from Genting Highlands in the Central Highlands of Peninsular Malaysia. Beccazia licin n. gen., n. sp. is atypical among potamids in possessing a bilobed terminal segment of the mandibular palp, and is only the second known member of the family with such a character; the other genus being the recently described Gempala bilobata $\mathrm{Ng} \&$ Ahmad, 2016, also from Peninsular Malaysia. All other congeners have a single terminal lobe on the mandibular palp. The carapace and third maxilliped morphology of Beccazia superficially resembles montane species of the Malaysian potamid Stoliczia Bott, 1966, but can easily be distinguished by its much smoother carapace, unarmed carpus of the cheliped and relatively wider male pleon.
\end{abstract}

LSID urn:lsid:zoobank.org:pub:1C4DED37-7984-46B0-8245-047D7E550534

Key words: Potamoidea, Potamidae, taxonomy, new genus, new species, mountain, Malaysia

\section{Introduction}

Herpetologists surveying the peak of Genting Highlands in the Central Range of Peninsular Malaysia recently collected a small freshwater crab at night which was passed to the author for study. While superficially resembling highland species of Stoliczia Bott, 1966 (family Potamidae Ortmann, 1896), in its smooth ovate carapace, slender ambulatory legs and the absence of a flagellum on the exopod of the third maxilliped; it possesses a bilobed terminal segment of the mandibular palp. Almost all potamids, however, have a single lobed terminal segment on the mandibular palp; a bilobed condition being a diagnostic character for freshwater crabs of the family Gecarcinucidae Rathbun, 1904 (cf. Bott, 1966, 1967, 1968, 1970; Ng, 1988, 2004; Cumberlidge \& Ng, 2009). The one exception to the potamid pat- tern of mandibular palp is the monotypic genus Gempala Ng \& Ahmad, 2016, described from the northeastern state of Terengganu in Peninsular Malaysia. Gempala has a bilobed terminal mandibular palp, but the appendage is still 3-segmented (Ng \& Ahmad, 2016); all gecarcinucids only have 2 segments on the palp (Bott, 1970; Ng, 1988).

In this paper, the Genting Highlands specimen is referred to a new genus and new species, Baccazia licin n. gen., n. sp. This is the second potamid with a bilobed terminal mandibular palp which is 3-segmented known from Peninsular Malaysia and Asia. The new genus and new species is described, figured and compared with allied genera.

The type specimen and comparative material examined are deposited in the Zoological Reference Collection (ZRC) of the Lee Kong Chian Natural History Museum, National Univer- 
sity of Singapore. Measurements, in millimetres, are of the maximum carapace width and length, respectively. The abbreviations G1 and G2 are used for the male first and second pleopods, respectively. The terminology essentially follows that by $\mathrm{Ng}$ (1988) and Davie et al. (2015).

\section{Taxonomy}

Superfamily Potamoidea Ortmann, 1896

Family Potamidae Ortmann, 1896

Subfamily Potamiscinae Bott, 1970, sensu Yeo \& Ng, 2004

Baccazia n. gen.

LSID urn:1sid:zoobank.org:act:EAA1FA67AC0F-432B-9D4C-783169B05CDE

\section{Type species}

Beccazia licin $\mathrm{n}$. sp., by present designation and monotypy.

\section{Diagnosis}

Carapace transversely ovate, wider than long (Figs. 1, 2A); dorsal surface convex in frontal view (Fig. 2B); dorsal and lateral surfaces of carapace smooth (Figs. 1, 2A, B); epigastric cristae barely visible, postorbital cristae not visible (Fig. 2A, B); external orbital tooth not demarcated from rest of entire anterolateral margin (Figs. 1, 2A); posterior margin of epistome with distinct broadly triangular median triangle, each lateral part with 2 distinct concave margins (Fig. 2B); mandibular palp distinctly 3-segmented; terminal article prominently bilobed, inner ovate lobe slightly larger than outer lobe (Fig. 3C-E); exopod of third maxilliped relatively slender, without trace of flagellum or lobe (Fig. 3A, B); outer surface of carpus of cheliped with inner distal angle rounded (Fig. 1); outer surface of chela smooth (Fig. 2F); ambulatory legs slender, long (Fig. 1 ); thoracic sternum (notably sternites 3,4 ) relatively broad transversely, surface smooth (Fig. $2 \mathrm{C}, \mathrm{E})$; sternopleonal cavity deep, reaching to

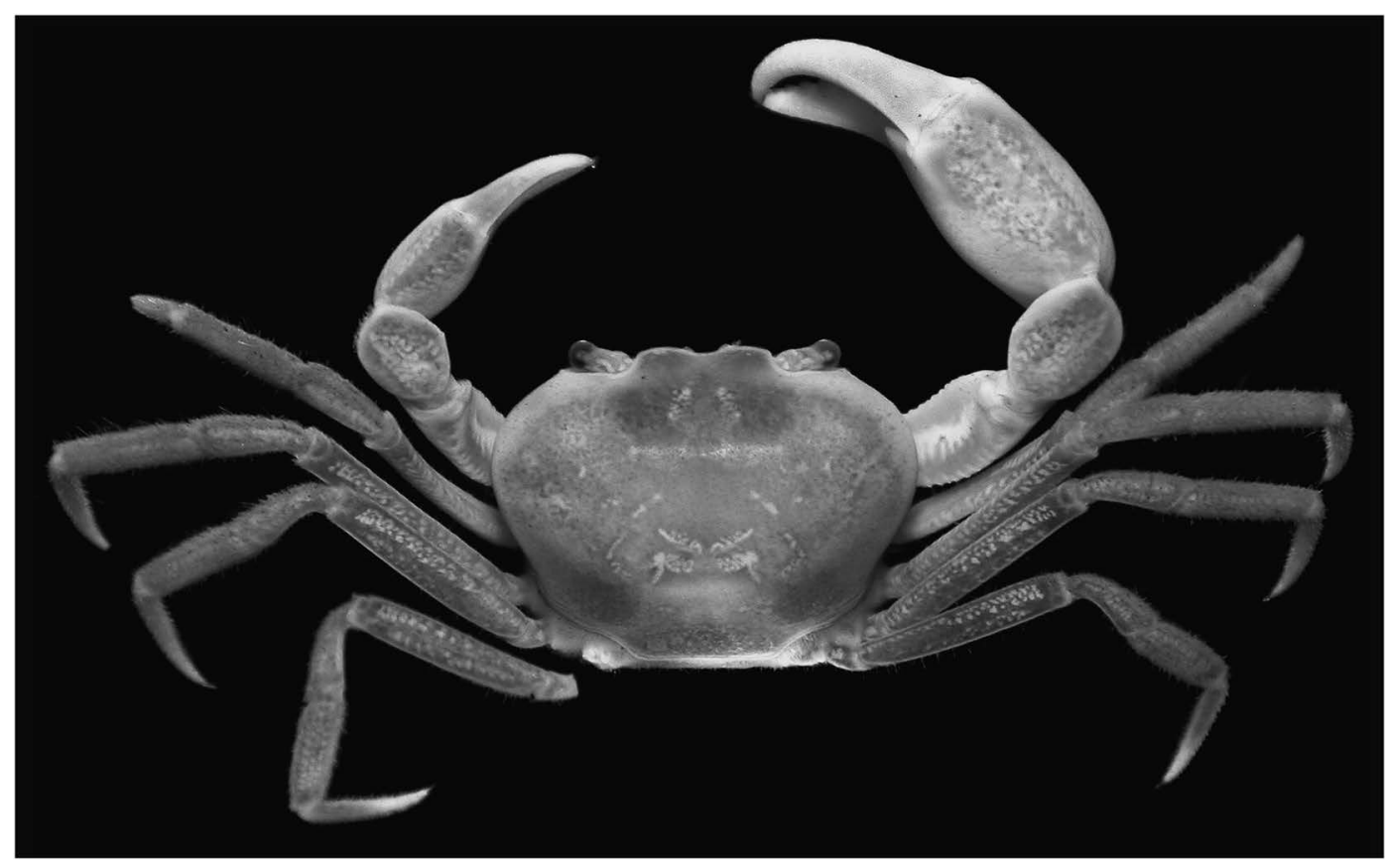

Fig. 1. Overall habitus, Beccazia licin n. gen., n. sp., holotype male $(12.6 \times 9.5 \mathrm{~mm})($ ZRC 2018.0253). 


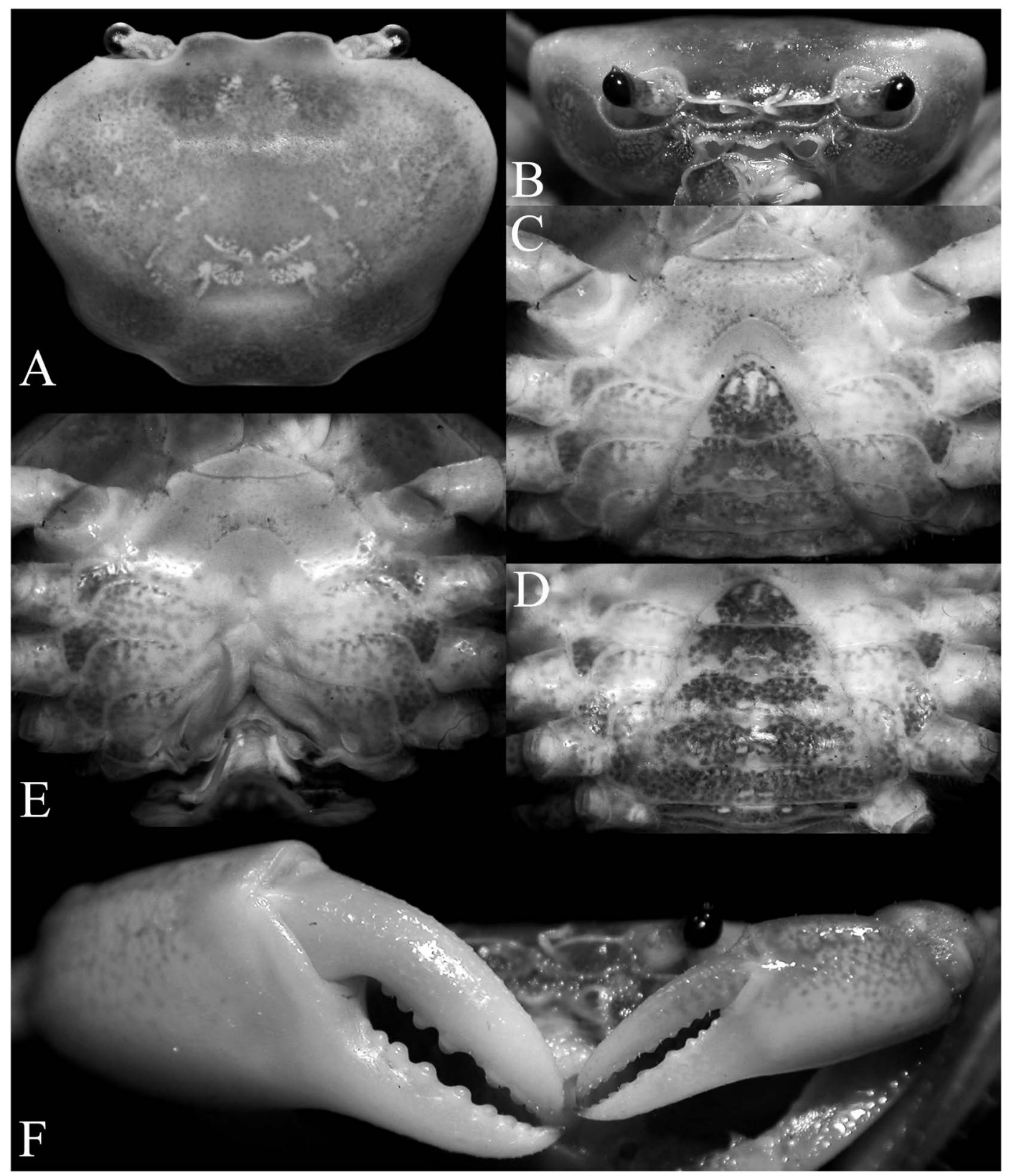

Fig. 2. Beccazia licin n. gen., n. sp., holotype male $(12.6 \times 9.5 \mathrm{~mm})($ ZRC 2018.0253). A, dorsal view of carapace; B, frontal view of cephalothorax; $\mathrm{C}$, anterior thoracic sternum, telson and pleonal somites 4-6; D, posterior thoracic sternum and pleonal somites 1-6; E, thoracic sternum and sternopleonal cavity; F, outer view of chelae.

imaginary line connecting median points of edges of cheliped coxae (Fig. 2C, E); male pleonal locking tubercle low, round, positioned on posterior half of sternite 5; male pleon broadly triangular, thoracic sternite 8 not visible when pleon closed (Fig. 2C, D); G1 with subterminal segment relatively stout; terminal segment curved outwards, strongly tapering to sharp tip (Fig. 3F-I); G2 distinctly longer than G1 (Fig. $3 \mathrm{~K})$. 


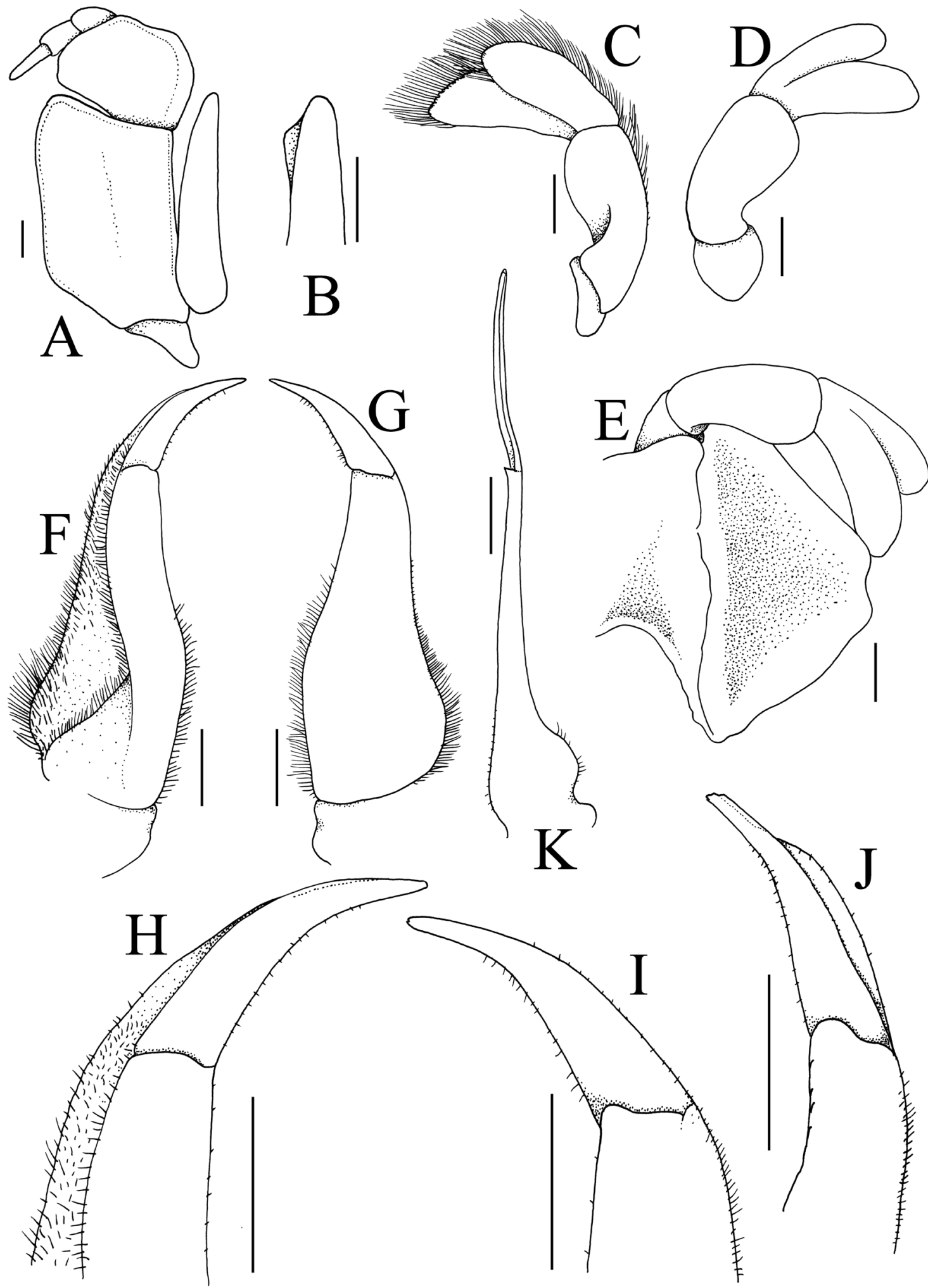




\section{Etymology}

The name is derived from the Latin word "bacca" for berry, alluding to the appearance of the carapace of the type species; in arbitrary combination with the suffix of the genus Stoliczia. Gender feminine.

\section{Remarks}

In its small adult size, smooth carapace, slender ambulatory legs and the exopod of the third maxilliped not possessing a flagellum, Baccazia n. gen. superficially resembles many species of Stoliczia Bott, 1966 (type species Stoliczia stoliczkana Wood-Mason, 1871), particularly those from montane habitats (see Ng, 1988, 1991, 1992, 1993; Ng \& Schubart, 2014). Sixteen species of Stoliczia are now known, all from Peninsular Malaysia ( $\mathrm{Ng}$ et al., 2008; Ng \& Schubart, 2014). Baccazia n. gen., however, can easily be separated by its more transversely ovate carapace with its relatively narrow frontal margin (Figs. 1, 2A) (versus carapace more quadrate with the frontal margin relatively wider in Stoliczia, cf. $\mathrm{Ng}$, 1988: figs. 29A, 31A, 33A, 34A; Ng \& Schubart, 2014: fig. 1A, B); the epigastric and postorbital cristae are completely undiscernible (Fig. 2A, B) (versus distinct or low but still visible in Stoliczia, cf. Ng, 1988: figs. 29A, 31A, 33A, 34A; Ng \& Schubart, 2014: fig. 1A, $\mathrm{B})$; the branchial regions are distinctly inflated (Fig. 2A, B) (versus branchial regions convex but distinctly less inflated in Stoliczia, cf. Ng, 1988: figs. 29A, 31A, 33A, 34A; Ng \& Schubart, 2014: 1B, C); and the male pleon is proportionately broader, especially somites 4 and 5 (Fig. 2C, D) (versus male pleonal somites 5 and 6 proportionately narrower in Stoliczia, cf. Ng, 1992: pls. 2B, 3B, 4C; Ng, 1993: pls. 3, 4; $\mathrm{Ng} \&$ Schubart, 2014: fig. 2A-C). Most signifi- cantly, the mandibular palp of Baccazia n. gen. is distinctly bilobed (Fig. 3C-E) whereas those of all Stoliczia species are single lobed. The author has re-examined the mandibular palps of all Stoliczia species and they are of the typical potamid condition (see Ng, 1988: fig. 2A).

The external morphology of Baccazia is markedly different from Gempala. Baccazia can most easily be separated by its transverse egg-like carapace which is not prominently raised (Figs. 1, 2A, B) (versus carapace almost quadrate and distinctly raised and high in Gempala; cf. $\mathrm{Ng} \&$ Ahmad, 2016: figs. 2, 3); the dorsal and lateral carapace surfaces are smooth (Figs. 1, 2A, B) (versus covered with distinct striae in Gempala; cf. Ng \& Ahmad, 2016: fig. $3 \mathrm{~A}, \mathrm{C}, \mathrm{D}, \mathrm{F})$; the inner angle of the carpus of the cheliped is unarmed and smooth (Fig. 1) (versus with distinct tooth in Gempala; cf. $\mathrm{Ng}$ \& Ahmad, 2016: fig. 4B); the male pleon is broadly triangular (Fig. 2C, D) (versus proportionately more narrow in Gempala; cf. $\mathrm{Ng} \&$ Ahmad, 2016: figs. 5B, 7B); and the G1 subterminal segment is proportionately stouter with the terminal segment long and tapering (Fig. 3F-I) (versus G1 subterminal segment proportionately more slender and the terminal segment short with a prominent dorsal flap in Gempala; cf. Ng \& Ahmad, 2016: fig. 7C-J).

\section{Baccazia licin n. gen., n. sp.}

(Figs. 1-3)

LSID urn:lsid:zoobank.org:act:5944373EE0AD-453E-ACDF-FAC27A05666B

\section{Material examined}

Holotype male $(12.6 \times 9.5 \mathrm{~mm}) \quad($ ZRC 2018.0253), in swampy area in forest below slope of base of telecommunications tower, Bukit Cincin, peak of Genting Highlands, $3^{\circ}$

Fig. 3. Beccazia licin n. gen., n. sp., holotype male $(12.6 \times 9.5 \mathrm{~mm})($ ZRC 2018.0253). A, left third maxilliped; B, distal half of exopod of third maxilliped (angled slightly laterally); C, left mandibular palp (outer view); D, left mandibular palp (inner view; setae not drawn); E, right mandible and palp (setae not drawn); F, left G1 (ventral view); G, left G1 (dorsal view); H, distal half of left G1 (ventral view); I, distal half of left G1 (dorsal view); J, distal half of left G1 (ventromesial view); K, left G2. Scales $=0.5 \mathrm{~mm}$. 
26'04.2”N 101 47'03.0”E, ca. $1700 \mathrm{~m}$ asl, Pahang, Peninsular Malaysia, coll. E. Quah, July 2016.

\section{Diagnosis}

As for genus.

\section{Description of male holotype}

Carapace transversely ovate, wider than long, width to length ratio 1.33 , not prominently raised; dorsal surface convex in frontal view (Figs. 1, 2A, B). Frontal region, dorsal surface, lateral parts of anterolateral and branchial regions smooth; regions barely indicated, median $\mathrm{H}$-shaped gastro-cardiac groove shallow; cervical grooves not visible; suborbital, pterygostomial and sub-branchial regions smooth, glabrous (Figs. 1, 2A, B). Epigastric cristae low, barely visible; postorbital cristae not visible (Fig. 2A, B). Frontal margin divided into 2 broad lobes, separated by shallow concavity; margin of each lobe convex, separated from supraorbital margin by blunt angle (Fig. 2A). External orbital tooth small, not demarcated from rest of entire anterolateral margin (Figs. 1, 2A). Anterolateral margins strongly convex, rounded, not cristate (Fig. 2A, B). Posterolateral margin concave, strongly converging towards almost straight posterior carapace margin (Figs. 1, 2A). Orbits ovate; eye filling up most of orbital space; eye peduncle relatively short, stout; cornea large, pigmented with tuft of setae on dorsal surface (Fig. 2A, B). Supraorbital margin entire, almost straight (Fig. 2A, B). Suborbital margin concave, complete, cristate (Fig. 2B). Antennae very short, just overreaching base of ocular peduncle; antennules short, folding transversely in narrow fossa (Fig. 2B). Posterior margin of epistome with distinct broadly triangular median triangle, separated from rest of margin by very shallow, indistinct groove, each lateral part with 2 distinct concave margins (Fig. 2B). Mandibular palp 3-segmented; terminal article prominently bilobed, inner ovate lobe slightly larger than out- er lobe (Fig. 3C-E).

Third maxillipeds covering most of buccal cavity when closed; ischium subrectangular, with very shallow, barely visible median oblique groove; merus subquadrate, slightly wider than long, anteroexternal angle not expanded; exopod relatively slender, reaching to half length of merus, without trace of flagellum or lobe (Fig. 3A, B).

Chelipeds prominently asymmetrical (Figs. 1, 2F). Anterior margin of basis-ischium uneven but not granulate; inner margin of merus lined with low broad, relatively blunt granules, appears gently serrate (Fig. 1). Outer surface of carpus almost smooth, inner distal angle rounded, with 2 very low tubercles, without spine or tooth (Fig. 1). Outer surfaces of chelae smooth; major chela very stout (Fig. 2F). Fingers of major chela gently curved, as long as palm (Figs. 1, 2F), outer surface with low granules and pits; cutting edges of both fingers with variously sized teeth (Fig. 2F). Fingers of minor chela slender, as long as palm (Figs. 1, $2 \mathrm{~F}$ ), otherwise similar to condition of major chela (Fig. 2F).

Ambulatory legs slender, long; second pair longest, last pair shortest; surfaces smooth (Fig. 1). Surface of merus smooth, covered with scattered setae, dorsal margin weakly cristate, slightly uneven, without subdistal spine or tooth; carpus smooth, without obvious median ridge, dorsal and ventral margins with dense short setae and scattered longer setae; outer surface of propodus without visible ridge, dorsal and ventral margins with dense short setae and scattered longer setae, laterally flattened; dactylus relatively long, gently curved, proximal half with dense short setae, margins with scattered longer setae, margins with short spines (Fig. 1).

Thoracic sternum (notably sternites 3,4 ) relatively broad transversely, surface smooth (Fig. $2 \mathrm{C}, \mathrm{E}$ ). Sternites 1, 2 completely fused to form broad triangular plate; separated from sternite 3 by distinct, gently concave suture; sternites 3 , 
4 completely fused except for shallow lateral transverse depression between sternites; sutures between sternites $4 / 5,5 / 6,6 / 7$ medially interrupted; suture between sternites 7,8 complete; deep longitudinal groove on sternites 7 and 8 (Fig. 2E). Penis short, tubular, coxal, on condyle of coxa of fourth ambulatory leg. Sternopleonal cavity deep, reaching to imaginary line connecting median points of edges of cheliped coxae (Fig. 2C, E). Male pleonal locking tubercle low, peg-like, positioned on posterior third of sternite 5 .

Pleon broadly triangular, all somites, telson free; telson triangular, lateral margins almost straight; somite 6 trapezoidal, much wider than long, lateral margins gently convex; somites 3-5 trapezoidal, gradually decreasing in width; somites 1, 2 subrectangular, narrow, very wide, reaching to bases of coxae of fourth ambulatory legs, thoracic sternite 8 not visible when pleon closed (Fig. 2C, D).

G1 with subterminal segment relatively stout, tapering towards clearly demarcated terminal segment; terminal segment distinctly curved outwards (from median part of sternum), strongly tapering to sharp tip (Fig. 3F-I). G2 distinctly longer than G1, distal segment slender, long, longer than half length of basal segment (Fig. 3K).

\section{Etymology}

The name is derived from the Malay word "licin" for smooth. The name is used as a noun in apposition.

\section{Remarks}

The type specimen was obtained at night from the edge of drain adjacent to a swampy area on Bukit Cincin, the highest point on Genting Highlands. Nothing else is known about its biology. From its physiognomy and elongated ambulatory legs, the species is probably semiterrestrial in habits, living in burrows. Crabs with these habits are often nocturnal, cryptic and hard to collect. Gempala bilobata
$\mathrm{Ng}$ \& Ahmad, 2016, from lowland forests in Terengganu is also semiterrestrial and was only collected recently in pitfall crabs in 2016, even though the type locality had been well surveyed in the past.

\section{Acknowledgements}

Thanks are due to Evan Quah and Ruth Mary Low for kindly passing this most interesting potamid to the author for study; and to two anonymous referees for their helpful comments.

\section{Literature Cited}

Bott, R., 1967. Potamiden aus Ost-Asien (Parapotamon De Man, Sinopotamon n. gen., Candidiopotamon n. gen., Geothelphusa Stimpson) (Crustacea, Decapoda). Senckenbergiana biologica, 48(3): 203-220.

Bott, R., 1968. Parathelphusiden aus Hinterindien (Crustacea, Decapoda, Parathelphusidae). Senckenbergiana biologica, 49(5): 403-422.

Bott, R., 1969. Flußkrabben aus Asien und ihre Klassifikation (Crustacea, Decapoda). Senckenbergiana biologica, 50(5-6): 359366.

Bott, R., 1970. Die Süßwasserkrabben von Europa, Asien, Australien und ihre Stammesgeschichte. Eine Revision der Potamoidea und der Parathelphusoidea (Crustacea, Decapoda). Abhandlungen der senckenbergischen naturforschenden Gesellschaft, 526: 1-338, figs. $1-8$, pls. 1-58, map 1 .

Cumberlidge, N., \& Ng, P. K. L., 2009. Systematics, evolution, and biogeography of freshwater crabs. In: J. W. Martin, K. A. Crandall, \& D. L. Felder (eds.), Crustacean Issues 18: Decapod Crustacean Phylogenetics, CRC Press, England, pp. 491-508.

Davie, P. J. F., Guinot, D., \& Ng, P. K. L., 2015. Anatomy and functional morphology of Brachyura. In: P. Castro, P. J. F. Davie, D. Guinot, F. R. Schram, \& J. C. von Vaupel Klein (eds.), Treatise on Zoology-Anatomy, 
Taxonomy, Biology. The Crustacea. Volume 9C-I. Decapoda: Brachyura (Part 1), pp. 11163.

Ng, P. K. L., 1988. The Freshwater Crabs of Peninsular Malaysia and Singapore. Department of Zoology, National University of Singapore, Shinglee Press, pp. i-viii, 1-156, figs. 1-63, 4 colour plates.

Ng, P. K. L., 1991. A note on the taxonomy of two Malayan freshwater crabs, Stoliczia rafflesi (Roux, 1936) and Stoliczia changmanae Ng, 1988 (Crustacea: Decapoda: Brachyura: Potamidae). Verhandlungen der Naturforschenden Gesellschaft Basel, 100: 91-97.

Ng, P. K. L., 1992. Crabs of the Stoliczia stoliczkana (Wood Mason, 1871) species complex (Crustacea: Decapoda: Brachyura: Potamidae). Malaysian Journal of Science, 14: $1-25$.

Ng, P. K. L., 1993. Freshwater crabs allied to Stoliczia tweediei (Roux, 1934) (Crustacea: Decapoda: Brachyura: Potamidae), with descriptions of two new species from Kedah and Perak, Peninsular Malaysia. Verhanderlingen der Naturforschenden Gesellschaft Basel, 103: 81-95.

Ng, P. K. L., \& Ahmad, A. B., 2016. A new genus and new species for an unusual semi-terrestrial potamid crab (Decapoda: Brachyura) with a bilobed mandibular palp from Peninsular Malaysia. Journal of Crustacean Biology, 36(6): 823-832.

Ng, P. K. L., Guinot, G., \& Davie, P. J. F., 2008. Systema Brachyurorum: Part I. An annotated checklist of extant brachyuran crabs of the world. Raffles Bulletin of Zoology, Supplement, 17: 1-286.

Ng, P. K. L., \& Ng, H. P., 1987. The freshwater crabs of Pulau Langkawi, Peninsular Malaysia. Malaysian Journal of Science, 9: 1-15.

Ng, P. K. L., \& Schubart, C. D., 2014. A new species of freshwater crab of the genus Stoliczia Bott, 1966 (Crustacea: Brachyura: Potamidae) from the summit of Bukit Larut, Perak, Peninsular Malaysia. Raffles Bulletin of Zoology, 62: 484-489.

Yeo, D. C. J. \& P. K. L. Ng, 2004. Recognition of two subfamilies in the Potamidae Ortmann, 1896 (Brachyura, Potamidae) with a note on the genus Potamon Savigny, 1816. Crustaceana, 76(10): 1219-1235.

\section{Address:}

(PN) Lee Kong Chian Natural History Museum, National University of Singapore, 2 Conservatory Drive, Singapore 117377, Republic of Singapore. E-mail: peterng@nus.edu.sg 